\title{
Climate, Energy and Community: Vermont 2018
}

\author{
Alan K. Betts \\ Atmospheric Research, Pittsford, VT 05763 \\ akbetts@aol.com \\ http://alanbetts.com/writings
}

This is a compilation of my 2018 columns from the Sunday Rutland Herald and Barre/Montpelier Time Argus. This is the eleventh year of a series that started in January 2008; and a 2012 overview paper is available ${ }^{1}$.These columns go through the seasons, dealing with weather, climate, climate change, energy and policy issues. They blend science and opinion with a systems perspective, and encourage the reader to explore alternative and hopeful paths for their families and society. They are framed so that a scientist will perceive them as technically accurate (although simplified); while the public can relate their tangible experience of weather and climate to the much less tangible issues of climate change, energy policy and strategies for living sustainably with the earth system. The politically motivated attacks on climate science by the current administration have however sharpened my political commentary; since climate change denial may bring immense suffering to our children and all life on Earth.

I believe that earth scientists have a responsibility to communicate clearly and directly to the public ${ }^{2}$-as we all share responsibility for the future of the Earth. We must deepen our collective understanding, if we are to we can make a collective decision to build a resilient future.

All my articles are available from my web-site, and can be freely reused under a Creative Commons license.

List of topics in 2018 [Index is live]

a) Intelligence and Resilience

b) Lessons from winter

c) Our responsibility to the Earth

d) What kind of America do we want?

e) Climate Change is on a roll

f) Faith, hope and the creation

g) The Climate Endgame is Coming
(February 10, 2018)..................................................2

(April 7, 2017).....................................................3

(June 2, 2018).....................................................5

(July 21, 2018)............................................... 7

(September 8, 2018)......................................................9

(October 27, 2018) ................................................ 11

(December 1, 2018)........................................................ 12

\footnotetext{
${ }^{1}$ Betts, A.K. and E. Gibson (2012), Environmental journalism revisited. Environmental Leadership: a Reference Handbook. Deborah R. Gallagher, Editor, SAGE publications Inc., Sept. 2012, ISBN: 9781412981507. Available at http://alanbetts.com/research/paper/environmental-journalism-revisited/\#abstract

${ }^{2}$ Betts, A. K. (2011), Communicating Climate Science. EOS Transactions, 92, No. 24, 14 June 2011. Available at http://alanbetts.com/research/paper/communicating-climate-science/\#abstract
} 


\section{a) Intelligence and Resilience}

(February 10, 2018)

\section{https://www.rutlandherald.com/articles/Intelligence-and-Resilence/}

I have been reflecting this winter on environmental intelligence, defined as that blend of natural science, social science and indigenous knowledge that helps us humans understand how to interact constructively and creatively with the living natural world. Our limited environmental intelligence has been apparent for years. Now we have a central government that is so deficient that its primary interest is exploiting the natural world to increase the profits of its corporate sponsors. The tacit assumption is that both current and future costs can be dumped on the poor, the indigenous, our children, and of course the Earth itself. In sharp contrast, the well-being of the planet, and our democracy, depend on how soon we the people recognize that we are all an integral part of this one Earth; and that we are being exploited by rich demagogues.

It won't take much to bring our proud society to its knees. Everything changed overnight on Puerto Rico when Hurricane Maria destroyed the power grid last September. Nearly five months have passed, and in the regions still without power, it is still day-to-day basic survival with little or no potable water, no refrigeration, no schools and no industry. Infrastructure including key bridges have not been rebuilt because the economy is bankrupt. Our financial system that exploited and pushed the country into bankruptcy, accepts no liability. Our government treats Puerto Rico as a now-worthless colony of foreigners that can be ignored, because they don't make large donations, and they certainly don't have a vote. This neglect of its own citizens is a measure of how far this once proud nation has sunk.

But desperate circumstances force us to return to community values: human disasters we can all understand. The community support here for my daughter's family who came to Vermont as refugees from Puerto Rico has been amazing and joyful to watch. Instinctively we remember that we cannot survive disasters as isolated individuals, only as a caring community.

Yet underneath, the creeping disaster to the planet threatens all our treasured values. Perhaps some of you made New Year resolutions to speak out for reality and the truth, which are now precariously intertwined, and essential for our survival. This year we need a conscious and determined effort to strengthen our communities and democratic values, and resist an economic and political system that would rather manipulate us as lonely individual consumers in the thrall of advertising and the media.

On a national level, the executive is trying to suppress the freedom of the press, as it struggles with pathetic desperation to create the first American dictatorship. The truth is rebranded as fake news, and puppet news media spread fabrications. Science and evidence are suppressed as dangerous, while the EPA dismantles environmental regulations related to clean air, clean water and mitigating climate change. Fortunately the Climate Advisory Panel that was dissolved last August was recreated in January by the Earth Institute of Columbia University and the State 
of New York. Cities, States and businesses want access to reliable information to adapt to our changing climate, as they intend to keep our commitments to the Paris climate agreement.

This is a good time to reflect on Franklin Roosevelt's State of the Union address in January 1941, before the US entered World War II. He described how the US stood for four essential human freedoms: freedom of speech, freedom of worship, freedom from want and freedom from fear - everywhere in the world. We must stand up for these American values in the face of efforts by the current administration to bury them all.

Our communities are our strength and our resilience. I have been reflecting on how the towns of Rutland County came together in the days after Tropical Storm Irene isolated many of them. Some towns had no power or cell service, so the local community simply met every morning to help those in need; while those with equipment started rebuilding washed-out roads. Some had to climb mountains to find cell service, but soon the flow of information across social networks reconnected us all, so we could collect and move food, water and resources across rough terrain. We rush to do this in crises: now we face ongoing crises which need the same courageous determination.

\section{b) Lessons from winter}

\section{(April 7, 2017)}

\section{https://www.rutlandherald.com/articles/lessons-from-winter/}

It has been a chilly and snowy winter in the northeast, while temperatures in the western US and Alaska have been high. Temperatures in the Arctic have been very high and the sea-ice cover has reached record low values. As the Arctic warms, the cold polar vortex weakens, and it has become more unstable. There have been large exchanges of warm air flowing into the Arctic and cold polar air sinking into eastern North America and then into Europe in March. These air-mass exchanges produced both our cooler winter and the warmer Arctic.

Snow cover locks in cold temperatures, because it reflects so much of the sun's energy that little snow can melt, until the sun is higher in the sky. But the winter has had some extreme transitions. When warm air come in from the south on January 11-12, temperatures which had been below zero soared to 60 degrees. The snow all melted, and to my surprise, the soil was unfrozen and I could dig under some of my cover crop.

By late March, we are eating spinach again that overwintered in a glass cold frame, buried under snow until last week. Our spring lettuce will soon be ready. The Rutland farmers' market has had mixed salad greens, grown in unheated greenhouses, since mid-February.

Last December the fuel efficiency of our Prius Prime plug-in hybrid dropped below 100mpg for the first time, as the battery is less efficient when cold, and $20 \%$ of its energy is used to heat the car. In contrast we average $160 \mathrm{mpg}$ in summer with a mix of short and long-range trips. Our 
average on the first 14000 miles is $134 \mathrm{mpg}$, which means we are burning only 90 gallons of gas per year. Plug-in hybrids reduce carbon emissions by $80 \%$ and are available now.

Global trade issues are in flux. The European Commission has backed a French call to make trade deals with Europe contingent on membership of the Paris climate agreement. This is a step forward towards global responsibility. And a small step towards holding the US government responsible for sacrificing the Earth's climate to protect the financial interests of its fossil carbon sponsors. However our president believes he can control trade using tariffs, so trade wars threaten.

The deeper economic issue is that climate change denial is driving a huge fossil carbon bubble. We face the collapse of the perceived value of fossil carbon assets and related industries, as well as the value of coastal property threatened by storm surges and sea level rise. Trillions of dollars of assets will lose their value as climate change accelerates. We would be wise to manage this transition using a little environmental intelligence.

At town meeting last month, 35 Vermont towns voted overwhelmingly in favor of resolutions seeking climate solutions. They urged the State of Vermont to meet its goals for $90 \%$ renewable energy, and called for a fair and equitable transition off fossil fuels. The majority of the resolutions also demanded a ban on any new fossil fuel infrastructure, such as natural gas pipelines. This is a stark but encouraging contrast with federal policy.

I am reminded how Vermont conservatives realized long ago that conserving the natural resources of the Earth was crucial for our society. I remember well Art Gibb, one of my neighbors in Weybridge, who led the Commission that drafted Act 250 in 1970. Yet strangely in our Nation's capital, many that claim to be conservatives do not see that conserving the climate of this planet is crucial for future life on Earth. Morally blind, they would sell our children's future to those who fund their election campaigns.

Yet spring is here again and very soon I will have the delight of planting frost-hardy seeds to rejoin the cycle of life. 


\section{c) Our responsibility to the Earth}

https://www.rutlandherald.com/articles/our-responsibility-to-the-Earth

\section{(June 2, 2018)}

Spring came late in Vermont, as the daffodils did not start opening in Pittsford till April 18, and the forsythia were ten days later. Rain for days on end from slow moving weather systems led to substantial flooding. The grass grew profusely weeks before it was dry enough to mow. I planted cool weather crops, lettuce, kale and broccoli by the first of May, and by now even the summer squash and tomatoes are growing fast.

Earth Day was a Sunday this year. In the morning I spoke at the Dorset Church about our failing to accept our deep responsibilities to the Earth. In the afternoon, I spoke to a group called 'Earth Matters' on the green in Manchester. The challenge we face is the same whether framed in spiritual or secular language: time is running out for humanity if we continue down the path of mindlessly exploiting the Earth for short-term profit.

The glaring question facing us all is: who is responsible for solving this mess?

In early May I spent a week in the mountains of Alberta, Canada speaking to an international meeting of hundreds of scientists working on global water and energy issues. The title of this open science conference was "Extremes and Water on the Edge". Introducing the conference, the Deputy Minister of Environment and Climate Change Canada explained how fast the Canadian north is changing as ice, snow and permafrost melt. Planning for the future is well underway, but the adaptation costs are immense. Ironically Alaska has just the same changing climate, but planning is very difficult, because federal policy requires them to pretend it isn't happening!

As the climate changes, so the global water and energy cycles are changing. The long-frozen north is melting; and floods, droughts and heat waves are becoming more frequent across the globe. Disaster response and future planning for resilience were hot topics. Scientists are in no doubt about what needs to be done to move away from a fossil fuel economy to a renewable energy economy; but traditionally scientists have preserved the integrity and independence of science by leaving policy to others. My message to this scientific community was that we all have a moral obligation to the Earth, especially earth scientists who can see clearly the dire future that lies ahead under 'business as usual'.

This moral responsibility of course extends to all of us; and it is time for citizens and professionals to speak up for the interests of all our children and life on Earth. We can no longer leave issues of 'policy' to a federal government that is simply ignoring all that we know about the climate system in order to protect the massive investments of the fossil fuel industry (who are bribing them).

Across the US and on a global scale, the renewable energy transition is going nowhere near fast enough to stave off disaster. The Earth's energy imbalance is about 1.3 watts per square meter and $93 \%$ of this extra energy is being stored in the oceans for the decades and centuries to come. 
This may seem small, comparable to a night-light, but it is about 250 times as large in total as the entire global electrical energy production. Rising sea level comes from this heating of the oceans, along with the melting of glaciers, which puts all our coastal development at risk. The flooding of New York by hurricane Sandy illustrates what happens when warmer seas give stronger storms with powerful storm surges along with higher sea-levels.

So redouble your efforts for the renewable energy transition. Work together to build creative synergistic solutions that will work for everyone, because so much is at stake, and discuss openly the moral issues we face with your colleagues and neighbors.

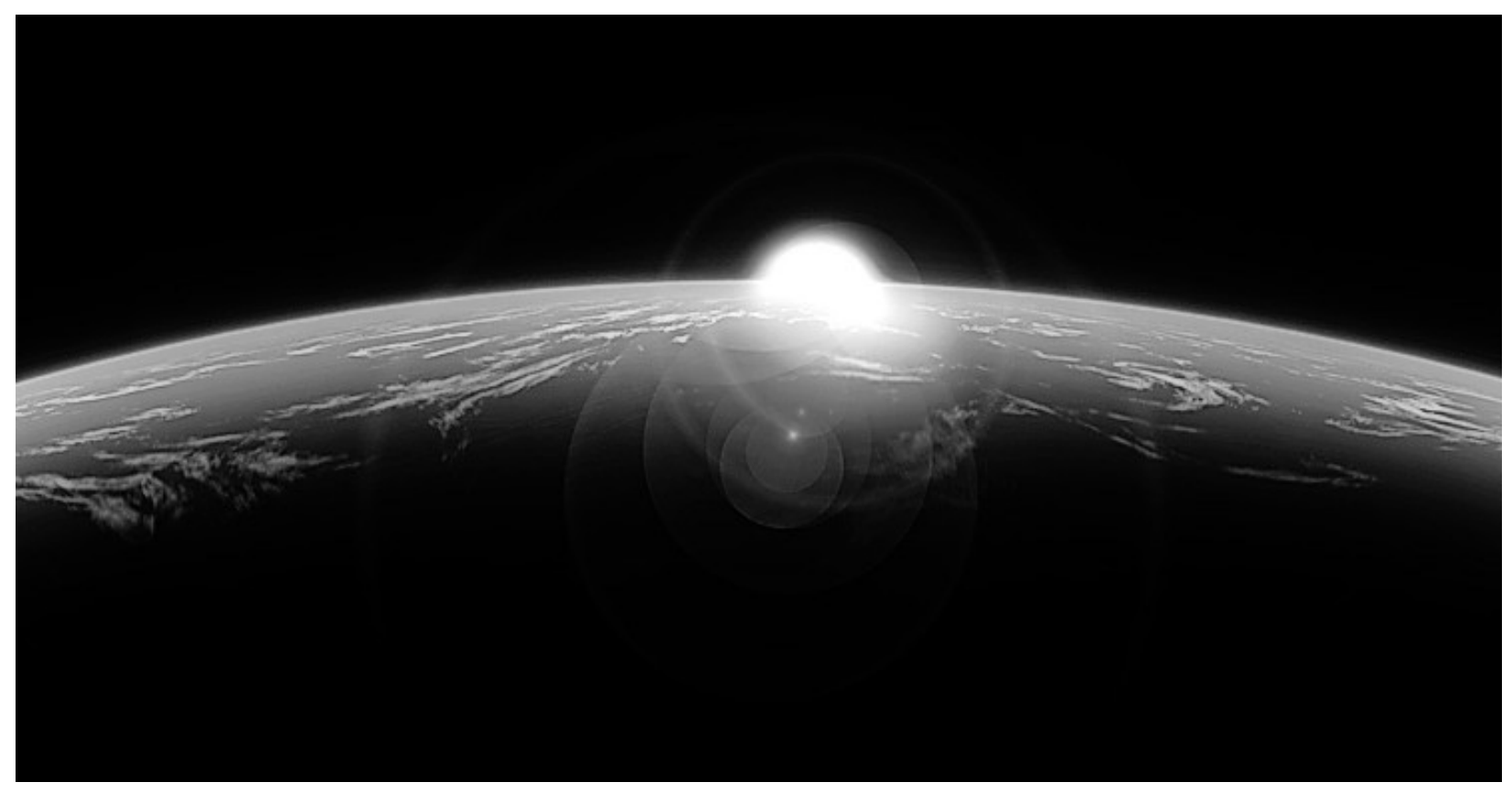




\section{d) What kind of America do we want? (July 21, 2018)}

https://www.rutlandherald.com/articles/what-kind-of-america-do-we-want/

Protection of the environment was once a national interest, one of the responsibilities of government to take care of the public interest and welfare; as well as the interests of endangered species. This was the bargain with capitalist America that left our corporations free to focus on maximizing profit and productivity; while the government took responsibility for the broader long-term interests of society, and local and global environmental issues. Now we have moved into a new political era, where this pact has disintegrated, and business and far-right wing groups have combined to dismantle this essential protective role of government.

For the business world this is comprehensible, because only benefit corporations are committed to making a positive impact on society, their workers, the community and the environment in addition to making a profit. But the other strand, the rise to power of an American version of fascism is new: one I never anticipated when I started writing Planet columns 10 years ago. But we must face it, because so much that we treasure in America and on the Earth is at stake.

Fortunately this new American fascism is not well-disciplined like earlier versions in Europe last century. Unfortunately, its financial resources are large, because it has the backing of many corporations lured by reduced corporate taxes and reduced government regulation. If the gullible electorate can be bought this November, American democracy is in deep peril.

The president, who yearns to be an absolute ruler, has aligned his interests with the so-called altright, a diverse collection of neo-fascists and white supremacists, along with the evangelical fundamentalists, who believe we should return to a white America with theirs the state religion. Our democracy is threatened because the Republican Party in Congress has abandoned even the pretense of having values and principles, and allied itself with this new American fascism that strongly supports the president.

Lies, scapegoats and brutality are everywhere. Family values clearly only apply to white families: 'non-white' refugees and asylum seekers can be treated with open cruelty and internment camps - to send a message not to come to white America for refuge. Of course we ignore the many US interventions in Central America in recent decades that have contributed to the misery of these refugees.

Here at home, the Environmental Protection Agency, established by Republicans in 1970, is threatened. Its corrupt administrator may have been fired, but the mission of the EPA has been changed from protecting human health and the environment to protecting polluting industries. We are shredding the protections of the Clean Air and Clean Water Acts to marginally increase corporate profits. The concept that we are all responsible for clean water and clean air for the future has vanished. The Republican Party is happy with this destruction of its principles, as long as it gets in return re-election payments from these businesses. Access by government scientists to the press has been curtailed to hide the dangers ahead from this policy shift. 
Long-term issues like climate change are being buried in today's EPA. The Earth may have almost infinite resources that we depend on; but since it has no money, it can be simply ignored, even though the downstream costs for life on Earth have become too vast to contemplate.

Now that this is all laid out, it is much easier to see the common threads between the cruel treatment of refugees, the exploitation of the poor, and the exploitation of the planet that was outlined so perceptively by the 2015 Papal Encyclical - that non-Catholic America mostly ignored. The immorality of putting short-term profit ahead of everything we treasure, whether the lives of our children, or life on Earth itself, cannot be hidden.

But the day of reckoning will come. Our national debt and our future debt to the planet are unpayable. Internally the president is attempting to discredit the federal government, and bully the free press in his quest for power. Externally, his fragile ego is attempting to bully the rest of the world: allies and competitors alike. This week, his insecurity drew him to side with Russia against the US intelligence agencies. All this has led to the collapse of US authority in the world.

None of this can be papered over by more transparent lies. Sadly it is hard to confront corruption in our government. It is hard to deal with the conflict between the mythology of our great democracy, with government by the people and for the people; and the callous whims of a president who thinks the US Constitution and the rule of law are dispensable.

But confront we must. Government used to be responsible for passing environmental laws and assessing taxes for the greater good of the people of America. Now we have a government where corporate and neo-fascist interests dominate, and government regulations are being repealed and dismantled for payment.

The clock is ticking. Our communities must get together this summer, and ask what kind of America we want. 


\section{e) Climate Change is on a roll}

http://www.rutlandherald.com/articles/climate-change-is-on-a-roll/

(September 8, 2018)

Vermont has seen a warm summer, but rainfall in Pittsford has been high enough that we have had a large vegetable crop, as well as far too many weeds!

Near-stationary waves in the jet stream produced record July temperatures in regions around globe, particularly in western US and Canada and across Europe. This is the face of climate change. Stationary high pressure regions produce long periods of warm dry weather with little cloud cover, so temperatures creep up and humidity falls. This sets the stage for drought that damages crops, and for the forest fires that have been burning across many regions.

California has had especially devastating fires. On July 26, a full-fledged firestorm in Redding, California, produced the strongest tornadic firestorm winds ever recorded, with winds over $140 \mathrm{mph}$ - as powerful as an F3 tornado. Between July 27 and September 1, the Mendocino fire complex burnt 459,000 acres, far larger than any other fire in modern state history. The smoke from these massive fires produced severe air pollution.

The summer climate off the coast of southern California is typically associated with a cold ocean and low clouds; but this summer, ocean temps reached 79F. People swarmed to the beaches and tropical marine life moved north into the region. In a bitter contrast, beaches in Florida were empty as a result of massive die-offs of marine life coming from the toxic red tide growing in the ocean along 130 miles of Florida's south-west coast. Inland in Florida, blue-green algae, which grow in warmer water that has been polluted by the runoff of nitrogen and phosphorous fertilizers, have poisoned rivers and lakes. These are the same cyanobacteria that are affecting Vermont's lakes, as we too are reluctant to manage our runoff from urban and rural landscapes.

The extremes of climate and the pollution of our waters are all indicators of society's reluctance to manage our waste-streams for the good of our children and all life on Earth. This is both our personal responsibility and the responsibility of government, but now short-term financial interests are taking precedence over smart long-term planning.

One dismal example is that the EPA is planning to roll back auto efficiency standards which were set to rise to an average of $54 \mathrm{mpg}$ for passenger vehicles by the model year of 2025 . The deceitful logic is convoluted. They are claiming that more efficient cars must be more costly, so people won't buy them; and older cars are less safe, so more will die in accidents. The fact that more efficient cars save money by burning less gasoline, which also reduces on-going climate change, is totally ignored, because the EPA has been told to ignore it.

This is deliberate cruelty to our children who will have to live with accelerating climate extremes, if we continue to burn all the fossil fuels this century. We can build much more efficient cars today that reduce gasoline consumption by $80 \%$, which cost no more to build and 
cost much less to maintain. In addition, computer assistance and collision avoidance radar does make them safer to drive.

Let me give an example from our own experience. We were amazed that our plug-in Prius Prime has averaged $136 \mathrm{mpg}$ on the first 21000 miles with no compromises. Its all-electric range is only 30 miles, but this is enough that local travel in Rutland County is mostly all electric. For long trips, this car quickly reverts to gas-electric hybrid mode, with a range of 600 miles on a tank of gasoline, because of its remarkable efficiency. Last month we toured the Canadian Atlantic provinces. We drove 2100 miles in two weeks, plugging in overnight on most days, and we averaged $82 \mathrm{mpg}$, far more than the 2025 standards. This is the most efficient car on the market, because of the tightly integrated electrical power, and the recharging when braking and going downhill. Most manufacturers will of course build them anyway for the much smarter global market; but the EPA wants to limit the availability of fuel efficient cars in the US to prop up the oil industry.

If you are reading this early on Saturday morning, September 8, there is still time to join today's educational walks and bike rides starting at 9:00 AM from the Vermont Farmers Food Center in Rutland that are part of the Peoples Climate Movement. The theme is Climate, Jobs and Justice.

CalFire firefighter Jake Hainey, left, and engineer Anna Mathiasen watch as a wildfire burns near Oroville, Calif., earlier this summer. AP PHOTO

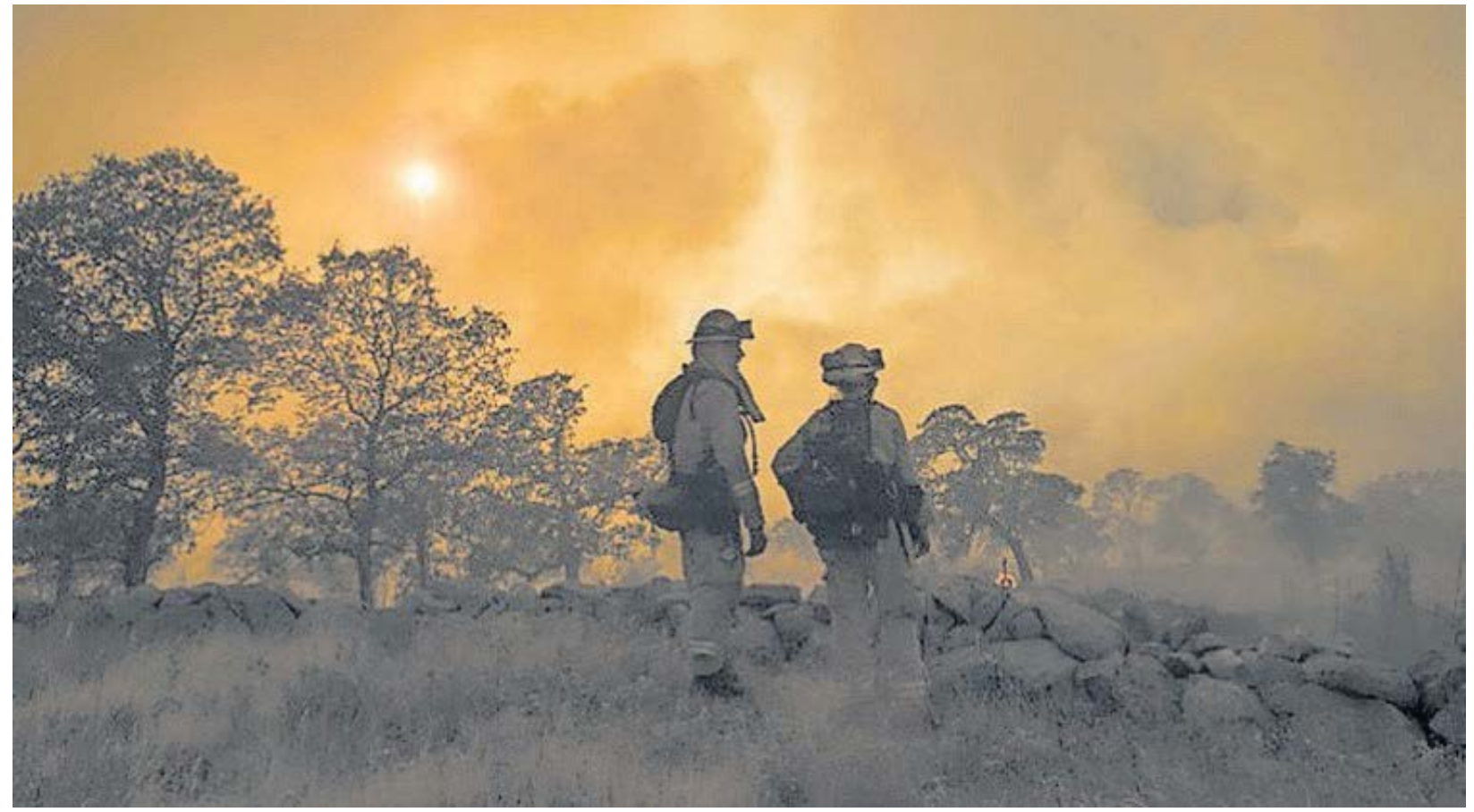




\section{f) Faith, hope and the creation}

\section{(October 27, 2018)}

https://www.rutlandherald.com/opinion/perspective/betts-faith-hope-and-thecreation/article 8e7e2b49-13e0-5042-9951-b41ff31977d3.html

I see poignant tragedy in Nassivera's recent column (Herald, October 20, 2018) about apocalyptic environmentalism and the loss of hope. Yes it is real: as we burn the fossil fuels and slow the cooling of the earth to space, more than $90 \%$ of the excess energy is being stored in the oceans, and much of the rest is melting ice in the Arctic. The climate is on a roll for centuries ahead, and more powerful storms and weather extremes are becoming more frequent. Our greed and selfishness will drive so many species to extinction.

Remarkably he seems unaware of how most churches have colluded in the blind march of humanity towards global environmental disaster; and how this in turn has contributed to the marginalization of the mainstream churches. The great exception was the 2015 Papal Encyclical that exposed in elegant detail the exploitation of the Earth and the poor by the amoral global capitalist economy. It was the fossil fuels that gave us the tremendous power to exploit on a global scale.

Looking back over the centuries, the churches were complicit in decimating the indigenous people's world view of humanity as a deeply interconnected part of a sacred natural world. Arrogantly convinced of their superiority, they opted for the church doctrine that humanity was above the created world (in E. F. Schumacher's language), and therefore free to exploit it; with the naive belief that humanity would be protected from the consequences.

But there is a deeper challenge in the ongoing rapid transformation of the human world, first by the industrial revolution driven by fossil fuels, and then the rise of science and technology to world dominance. We invent things and if they can be marketed by individuals and corporations to make a profit, they usually are, without any social or moral controls. So the freedom to exploit and pollute on a global scale goes unchecked, mindless of the future survival of the natural world that we all depend on. On all these critical issues, separation of church and state has meant that the church has been largely silent. Just when moral guidance is needed, it is easier to retreat into the familiar comfortable walls of century-old doctrine, tacitly complicit in the amoral transformation of the Earth. All around us, we see society and its institutions clinging to the gospel of business as usual, enshrined in the freedom of the global market to exploit humanity and the created world.

Certainly we need the virtues of faith and hope, but rooted in the present reality not in the past. Over the centuries, the definition of faith was shifted from understanding the interconnected unseen web of the creation into believing and accepting church doctrine, so as to protect the church hierarchy. Hope changed into our dreams and wishes for the future, rather than the powerful grounded motivating force which sees and creates a path to the future; as in 'Thy will be done on Earth'. 
Deep humility, clarity of vision and the virtues of faith, hope and love would realign humanity as a community with the interdependent living creation. For most of us, this means sitting in the wilderness and listening deeply till we reconnect. That was exactly what Christ Jesus did; but 2000 years on, the churches suffer when they do not follow his lead.

\section{g) The Climate Endgame is Coming (December 1, 2018) \\ https://www.rutlandherald.com/opinion/perspective/betts-climate-endgame-is- coming/article_be56881b-fde6-5268-9204-871e5fe62fc0.html}

Since the industrial revolution, the rich nations have exploited the Earth's resources and its people. But the end-game is coming. For the past 25 years, as the climate crisis has deepened, we have opted to sacrifice our children's lives and the future of the Earth for short-term profit, rather than implement obvious solutions. The argument is that the free market has enriched us all, and especially the rich and powerful. Any restraints or regulations or fossil carbon taxes might limit profits and our material growth. This doctrine has brought a climate catastrophe to our children's doorstep, and much of life on Earth will be affected. The most recent IPCC report is very blunt and very thorough, saying we have just 12 years to drastically reduce fossil fuel emissions. Many things are coming into focus that are not being discussed.

The global market needs guidelines: so that it is not allowed to exploit the future of the earth and humanity. We have to place value on the future, and assess the real costs of burning all the fossil fuels. Science needs guidelines and management. We invent things and if someone can market them profitably, we simply accept the consequences, even if they prove disastrous for society. The rationalization again is that freedom to profit and exploit is a right.

One hidden challenge for the US is that the concept of community responsibility got lost in the fear of communism. The communist political model collapsed as it led to centralized corruption; and now the capitalist free market model has also led to centralized corruption. New political models are needed that respect the future of the Earth. Damage to the future must be priced in as a cost, and this means real community discussion now. This will be difficult as the costs are rapidly growing. Nonetheless, every trillion we invest now in the transformation to an efficient society powered by renewable energy, will save our children about sixty trillion dollars later this century. If we stand by and watch, the present corrupt system will continue, in which the powerful can buy politicians to protect their profits with no thought for the future.

Scientists know that complex systems can go unstable if there are no restraining feedbacks. Now the climate system is moving towards instability. As the Arctic melts, methane is released from the permafrost. The jet stream patterns and mid-latitude weather are changing, as the Arctic warms faster than the tropics. As more and more heat is stored in the oceans, tropical storms become more powerful and dangerous. You will have heard about hurricanes Florence and Michael that struck N. Carolina, Florida and Georgia. You may have heard about the tropical storms that hit Hawaii this year; but you may not have heard about the most powerful 
storm of the year: super-typhoon Yutu that devastated the US Northern Mariana Islands in the western Pacific.

In Washington, the central government is simply ignoring reality, and even suggesting at times that climate change is a hoax. Recently, the president blamed California's tragic fires on forest management, unaware that in the western US, July to September were very dry with a new high temperature record. This set the stage for devastating fires.

Back in 2012, North Carolina legislators passed an astonishing bill that barred policymakers and developers from using up-to-date climate science to plan for rising sea levels on the state's coast, because updated flood zones would restrict development and reduce property values. The climate system paid no attention. The storm surge and 25 inches of rain from hurricane Florence simply drowned the stupidity of the North Carolina legislators, causing immense damage. But will rebuilding in flood zones still be permitted?

I suggest we step away into the Indigenous people's world view. All of humanity and life on Earth and the climate system have deep interconnections, which must be understood and respected. Anything else is human folly. 